\title{
RAPID TRANSPORT OF PROTEIN IN THE OPTIC SYSTEM OF THE GOLDFISH ${ }^{1}$
}

\author{
J. S. Elam ${ }^{2}$ and B. W. AgranofF \\ Mental Health Research Institute, University of Michigan, Ann Arbor, Michigan, U.S.A.
}

(Received 12 May 1970. Accepted 8 July 1970)

\begin{abstract}
Several amino acids, particularly $\left[{ }^{3} \mathrm{H}\right]$ proline and $\left[{ }^{3} \mathrm{H}\right]$ asparagine specifically and efficiently labelled rapidly transported proteins in the goldfish optic nerve and tectum after intraocular injection. Studies with these amino acids showed that the rapidly transported proteins moved as a discrete band at a rate which was temperature-dependent, and was equal to $70-100 \mathrm{~mm}$ per day at $20^{\circ} \mathrm{C}$. Transported protein in the optic tectum was 80 per cent particulate and was found in synaptosomal, mitochondrial, and myelin fractions, but not in purified nuclei or ribosomes.
\end{abstract}

STUDIES on various mammalian and sub-mammalian species have demonstrated that protein is transported in axons at rates ranging from less than $1 \mathrm{~mm}$ per day to several hundred mm per day (LUBINSKA, 1964; WEISs, 1967; KARLSSON and SJÖSTRAND, 1968; LASEK, 1968; LiveTt, GEFFEN and Austin, 1968; OCHS and Johnson, 1969; Sjöstrand, 1969). Protein is reportedly transported in the optic nerve of the goldfish with at least two discrete rates, about $40 \mathrm{~mm}$ per day and $0.4 \mathrm{~mm}$ per day (MCEwEN and GRAFSTEIN, 1968). The rapidly transported protein was detected after injection of $\left[{ }^{3} \mathrm{H}\right]-$ leucine into one eye by observing that within 6-12 h the radioactivity in the protein of the contralateral optic tectum was approximately double that of the ipsilateral optic tectum. Since free leucine apparently does not traverse the optic nerve, the excess of label in the contralateral tectum was presumably in protein transported from retinal ganglion cells in the injected eye to their corresponding nerve endings in the tectum. In the goldfish, the optic tracts are completely crossed and the tectum is a well-defined and easily removable brain area. These factors facilitate the study of transported protein in the nerve ending region. A complicating factor in such experiments is the high background labelling, as represented by the labelled non-transported protein in the ipsilateral tectum. This complication means that all calculations of transported radioactivity require the subtraction of one large number (ipsilateral radioactivity) from another large number (contralateral radioactivity). In the present study this complication was largely overcome by the use of amino acids which favourably label the transported protein. Studies on the kinetics of transport and subcellular distribution of protein labelled in this manner are presented.

\section{METHODS}

Fish storage and injections. Goldfish (Carassius auratus), 6-7 cm in body length, were obtained and stored as described previously (LIM and AGR ANOFF, 1969). Unless otherwise noted, fish-tank temperatures ranged from 18 to $23^{\circ} \mathrm{C}$. In controlled temperature experiments the fish tanks were suspended

${ }^{1}$ This work was supported by grant MH 12506 of the National Institute of Mental Health and GB-5125X of the National Science Foundation.

${ }^{2}$ Interdisciplinary fellow, supported by Training Grant MH 07417 from the National Institute of Mental Health.

Abbreviations used: INT, 2-(p-iodophenyl)-3-(p-nitrophenyl)-5-phenyltetrazolium chloride. 
in a constant temperature water bath. Tritiated amino acids were obtained from Schwarz Bioresearch (Orangeburg, N.Y.) and New England Nuclear Corp. (Boston, Mass.). Glycine and glutamic acid were adjusted from 20 to $6.5 \mathrm{Ci} / \mathrm{mmol}$ by addition of unlabelled amino acid. Other amino acids were adjusted to appropriate concentrations by dilution with distilled water or by evaporation to dryness under nitrogen and resuspension in distilled water. Intraocular injections in a volume of $5 \mu \mathrm{l}$ were made into the posterior chamber of the right eye using a $50-\mu$ I syringe fitted with a polyethylene sleeve.

Homogenization and subcellular fractionation. At designated times the brains were removed and the tecta were dissected out. In some experiments the optic nerve between the base of the eye and the optic chiasm was also removed. Homogenates $(10 \%, w / v)$ of one to five tectal hemispheres or nerve sections were made in $\mathbf{0 . 2 5} \mathrm{M}$-sucrose using a glass-to-glass homogenizer. For preparation of subcellular fractions, $20-40$ pooled tecta were disrupted in 9 vol. of $0.25 \mathrm{M}$-sucrose with a motor-driven Teflon-to-glass homogenizer. These homogenates were subfractionated into 'nuclear', 'mitochondrial', 'microsomal' and 'soluble' fractions by consecutive centrifugations of $750,11,500$ and $100,000 \mathrm{~g}$ for 10,20 and $60 \mathrm{~min}$, respectively. The crude mitochondrial fraction was further subdivided into myelin, synaptosomal and purified mitochondrial subfractions on a discontinuous gradient as described by VoN Hungen, MAHLER and MOORE (1968). The gradient consisted of the following sucrose layers: $10 \mathrm{ml}$ of $1.2 \mathrm{M}-, 5 \mathrm{ml}$ of $1.1 \mathrm{M}$ - and $5 \mathrm{ml}$ of $0.8 \mathrm{M}$-sucrose, all in $1 \mathrm{~mm}$-tris-HCl buffer (pH 7.4). Centrifugation was for $2 \mathrm{~h}$ at $25,000 \mathrm{rev} . / \mathrm{min}(53,000 \mathrm{gav}$.$) in a \mathrm{SW}-25$ rotor. Nuclei were further purified by adjusting the crude nuclear fraction to $1 \mathrm{mM}$ with respect to potassium phosphate buffer (pH 6.5) and $2 \mathrm{mM}$ with respect to $\mathrm{CaCl}_{2}$, and centrifuging through $2 \mathrm{M}$-sucrose in a SW-40 rotor at 22,500 rev./min $(65,000 \mathrm{~g})$ for $1 \mathrm{~h}$ (CASOLA and AGRANOFF, 1968). Ribosomes were isolated by suspending the microsomal pellet in a solution of 50 mm-tris- $\mathrm{HCl}$ buffer (pH 7.4), $5 \mathrm{~mm}-\mathrm{MgCl}_{2}, 25 \mathrm{~mm}-\mathrm{KCl}$ and $250 \mathrm{~mm}$ RNase-free sucrose. The mixture was treated at $4^{\circ} \mathrm{C}$ with $0.5 \%(\mathrm{w} / \mathrm{v})$ deoxycholate for $15 \mathrm{~min}$ and the lysate centrifuged at $37,000 \mathrm{rev} . / \mathrm{min}(170,000 \mathrm{~g}, \mathrm{SW}-40$ rotor) for $90 \mathrm{~min}$ on a $15-40 \%(\mathrm{w} / \mathrm{v})$ continuous sucrose gradient containing tris, $\mathrm{MgCl}_{2}$ and $\mathrm{KCl}$ as above.

Measurement of radioactivity. Protein from homogenates or subcellular fractions was prepared for counting by a modification of the filter paper method of MANS and Novelli (1961). Suspensions $(0.1-0.2 \mathrm{ml})$ were applied to discs of diameter $4.25 \mathrm{~cm}$ of Whatman No 2 filter paper suspended over a wooden board by tripods of small nails, and dried at room temperature. From 2 to 30 of the dried dises were placed in a beaker containing $10 \mathrm{ml}$ of cold $10 \%(\mathrm{w} / \mathrm{v}) \mathrm{TCA}$ per disc. When TCA-soluble counts from individual samples were desired, each disc was added to an individual $100-\mathrm{ml}$ beaker containing $10 \mathrm{ml}$ of $10 \%$ TCA. After precipitation with the cold TCA, the samples were treated successively with similar volumes of $10 \%(\mathrm{w} / \mathrm{v}) \mathrm{TCA}$ at $80^{\circ} \mathrm{C}$ for $30 \mathrm{~min}, 95 \%$ (v/v) ethanol, absolute ethanol, and twice with ether. The discs were air dried, cut into eight pieces and placed in counting vials. Hyamine $(1 \mathrm{ml})$ was added and the vials were heated at $80^{\circ} \mathrm{C}$ for $2 \mathrm{~min}$. Protein was counted in $10 \mathrm{ml}$ of scintillant containing $4 \mathrm{~g}$ of 2,5 -diphenyloxazole and $250 \mathrm{mg}$ of $p$-bis-2-(5-phenyloxazolyl)benzene per litre of toluene. Counting of $1 \mathrm{ml}$ or less of the TCA-soluble fractions was done in $12 \mathrm{ml}$ of the toluene scintillant containing $17 \%(\mathrm{v} / \mathrm{v})$ BBS-3. All samples were corrected to d.p.m. using an internal tritium standard. For low activity samples, nylon vials (Nuclear Chicago, Des Plaines, Ill.) were used. The background was 7 c.p.m. and the efficiency was 38 per cent in a Packard 3000 Counter. In a Tricarb 3375 counter with bialkaline photodetectors, the background was 12 c.p.m., and the efficiency was 60 per cent.

Hydrolysis of protein and thin-layer chromatography of amino acids. Homogenates labelled with $\left[{ }^{3} \mathrm{H}\right]$ proline or $\left[{ }^{3} \mathrm{H}\right]$ asparagine were precipitated in cold $10 \%(\mathrm{w} / \mathrm{v})$ TCA and extracted with hot TCA, ethanol, and ether. The protein residue was hydrolysed under nitrogen in a sealed tube in $6 \mathrm{M}-\mathrm{HCl}$ at $110^{\circ} \mathrm{C}$ for $48 \mathrm{~h}$. The hydrolysate was dried under nitrogen, redissolved in a small volume of water and dried twice, redissolved in a small volume and chromatographed in one dimension on plates of silicagel $\mathrm{G}$ (Analtech, $\mathrm{Co}$, Wilmington, Del.). The developing solvents were $n$-butanol-acetic acid-water $\left(80: 20: 20\right.$, by vol.) for experiments with $\left[{ }^{3} \mathrm{H}\right]$ proline, and $n$-propanol-ammonium hydroxide $(70: 30$, $\mathrm{v} / \mathrm{v}$ ) for experiments using $\left[{ }^{3} \mathrm{H}\right.$ ]asparagine (BRENNER, Niederwieser and PatakI, 1969). Unlabelled amino acids were cochromatographed as markers. Spots were visualized by ninhydrin, scraped into scintillation vials, and radioactive material was released by treatment with $0.5 \mathrm{ml}$ of $0.1 \mathrm{M}-\mathrm{HCl}$ for $4 \mathrm{~h}$. Toluene scintillant $(12 \mathrm{ml})$ containing $17 \%(\mathrm{v} / \mathrm{v})$ BBS-3 was added for counting.

Chemical and enzymic assays. RNA and DNA were extracted by alkaline hydrolysis and treatment with hot perchloric acid as described by CASOLA, LIM, DAVIS and AGRANOFF (1968). Amounts of RNA were calculated from absorbance at $260 \mathrm{~nm}$ and DNA was measured by the two-wavelength absorbancy method of SANTEN and AGRANOFF (1963).

Acetylcholinesterase was assayed by the method of Ellman, Courtney, ANDres and FeatherSTONe (1961). Assays were carried out in $0.5 \mathrm{ml}$ microcuvettes at $37^{\circ} \mathrm{C}$ (DAvis, 1968). Optical density at $412 \mathrm{~nm}$ was measured with a Gilford 220 optical density converter and a Sargent recorder. Enzyme units are expressed as moles of substrate cleaved per liter per min.

Succinate-INT-reductase [EC 1.3.99.1] was assayed as described by SELLINGER and HIATT (1968). 
The INT-[2-( $p$-iodophenyl)-3-( $p$-nitrophenyl)-5-phenyltetrazolium chloride] was purchased from Sigma Chemical Co. (St. Louis, Mo.). Recovery of enzyme activity was increased by preincubating the incubation mixture at $0^{\circ} \mathrm{C}$ for $30 \mathrm{~min}$ and by using controls in which $0 \cdot 1 \mathrm{M}$-malonate was substituted for succinate. Enzyme units are expressed as optical density change produced per hour. Protein was measured by the method of LoWry, Rosebrough, FarR and Randall (1951).

Cerebroside in subcellular fractions was measured qualitatively. A portion of the fraction to be examined containing $1 \mathrm{mg}$ of protein was mixed with $3.75 \mathrm{vol}$. chloroform-methanol $(1: 2 \mathrm{v} / \mathrm{v})$ followed by $1.25 \mathrm{vol}$. of chloroform and 1.25 vol. of $2 \mathrm{M}-\mathrm{KCl}$ (BLIGH and DYER, 1959). The sample was centrifuged and the lower phase aspirated and dried. After suspension in chloroform, the extract was plated on thin layer plates of activated silica-gel G, and chromatographed in parallel with a cerebroside standard in chloroform-methanol-water $(65: 25: 4$, by vol.) (W AGNER, Hörhammer and WOLFF, 1961). Spots were visualized by charring with conc. $\mathrm{H}_{2} \mathrm{SO}_{4}$.

\section{RESULTS}

Studies with $\left[{ }^{3} H\right]$ leucine. Goldfish were injected in the right eye with $15 \mu \mathrm{Ci}(1 \cdot 1 \mathrm{nmol})$ of $\left[{ }^{3} \mathrm{H}\right]$ leucine and the specific radioactivity of the protein in the left and right optic tecta was determined at various times after injection. Data from three to five individually analysed fish were averaged for each time point (Fig. 1). Within a few

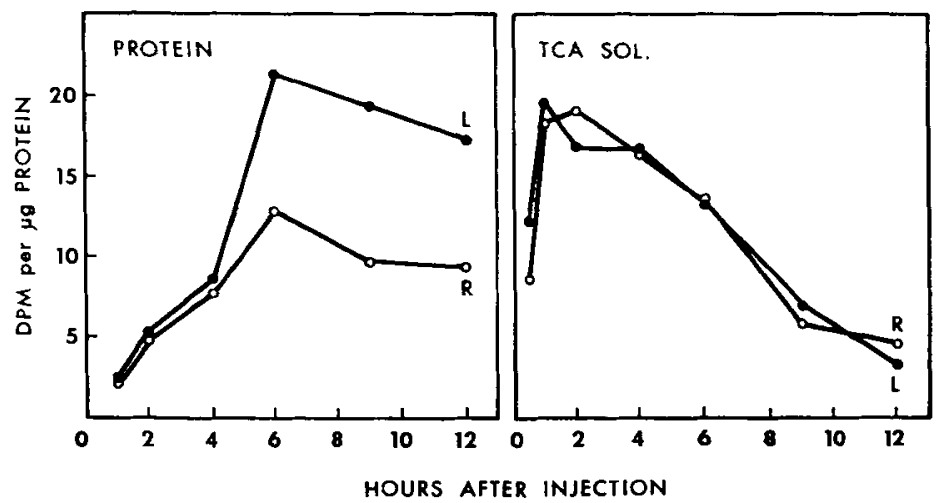

FIG. 1.-Labelling of the protein and TCA-soluble fractions in the left and right optic tecta at various times after intraocular injection of $\left[{ }^{3} \mathrm{H}\right.$ )leucine. Data from three to five fish were averaged for each point. Injection of $15 \mu \mathrm{Ci}(1.1 \mathrm{nmol})$ in $5 \mu$ ] was into the right eye. Protein and radioactivity were measured as described in Methods. TCA-soluble radioactivity is plotted as d.p.m. per $g$ of homogenate protein. $L$, left tectum; $R$, right tectum.

hours after injection the specific radioactivity of the left (contralateral) tectum significantly exceeded that of the right tectum. The difference in left-right labelling was not evident for the first 2-4 h and approached a maximum by 6-8 h. As found by MCEWEN and GRAFSTEIN (1968), there was never a corresponding left to right difference in TCA-soluble counts (Fig. 1).

We attempted to reduce the proportion of label in the right tectum by injecting a 'chase' dose of $34 \mu \mathrm{mol}$ of unlabelled leucine intraperitoneally, $15 \mathrm{~min}$ after $\left[{ }^{3} \mathrm{H}\right]$ leucine was injected intraocularly. There was some increase in the fraction of the label appearing on the left side (Fig. 2). However, the advantage tended to be offset by the decrease in absolute levels of incorporation, as compared with that illustrated in Fig. 1.

Studies with other amino acids. In a further attempt to increase the specificity of labelling of the rapidly transported proteins, $0.2-0.5 \mathrm{nmol}$ of 19 different tritiated 


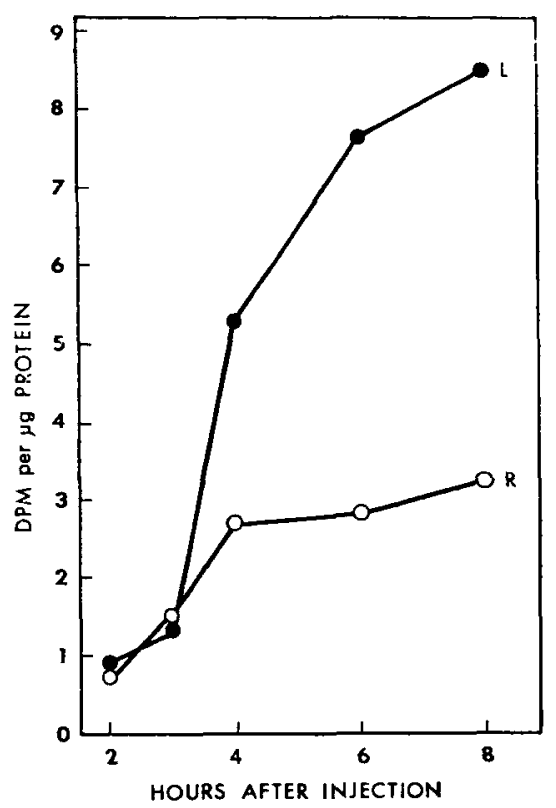

Fig. 2.-Labelling of protein in the left and right optic tecta and the remainder of the brain by intraocular injection of $\left.{ }^{3} \mathrm{H}\right]$ leucine $(15 \mu \mathrm{Ci}, 1 \cdot 1 \mathrm{nmol})$ followed by intraperitoneal injection of $34 \mu \mathrm{mol}(200 \mu \mathrm{l})$ of unlabelled leucine. Data from five fish were averaged from each point. $L$, left tectum; $R$, right tectum.

amino acids were injected into the right eye, and tectal labelling was measured $6 \mathrm{~h}$ later. Three groups of five pooled tecta were used for each amino acid. A summary of the results appears in Table 1. Although similar absolute amounts of the amino acids were injected, the differences in specific radioactivities resulted in injection of varying amounts of radioactivity. The labelling specificity is thus expressed as the dimensionless quotient $L / R$. An indication of the relative efficiency of labelling by the various amino acids is given in the expression $(\mathrm{L} / \mathrm{R}) / \mu \mathrm{Ci}$ injected. Amino acids are listed (Table 1 ) in the order of decreasing specificity in labelling the left tectum. Aspartic acid in the amounts injected $(0.6 \mu \mathrm{Ci} ; 0.28 \mathrm{nmol})$ gave too few counts to measure by our procedures. Labelled glutamine with high specific activity was not available. The other amino acids differed considerably in both the specificity of labelling and in the efficiency of incorporation. At the concentrations used, proline and asparagine appeared to be the most favourable in both respects. TCA-soluble radioactivity was also examined and did not differ measurably between left and right tecta in all cases except for proline (see below).

Kinetics of transport of protein labelled with proline and asparagine. A study of the time courses for tectal labelling with $\left[{ }^{3} \mathrm{H}\right]$ proline and $\left[{ }^{3} \mathrm{H}\right]$ asparagine (Fig. 3) showed that there was a delay of $2-4 \mathrm{~h}$ in the arrival of labelled transported protein and a subsequent rapid accumulation in the next 4-5 h. In dramatic contrast to the experiments with $\left[{ }^{3} \mathrm{H}\right]$ leucine, the specific radioactivity of the right tectum remained low at all times and $L / R$ values of $15-30$ were found. The apparent dip in the specific radioactivity of the left tectum at about $9 \mathrm{~h}$ was commonly seen in these experiments, but 
TABLE 1.-INCORPORATION OF $\left[{ }^{3} \mathrm{H}\right]$ AMINO ACIDS INTO LEFT AND RIGHT TECTAL PROTEIN

\begin{tabular}{cclcc}
\hline$\left.{ }^{3} \mathrm{H}\right]$ Amino acid & nmol $(\mu \mathrm{Ci})$ injected & L/R* & $(\mathrm{L}-\mathrm{R}) / \mu \mathrm{Ci}$ injected \\
\hline Pro & 0.48 & $(0.24)$ & 17.0 & 1.34 \\
Asn & 0.43 & $(0.52)$ & 15.1 & 1.69 \\
Ala & 0.43 & $(2.3)$ & 7.5 & 0.15 \\
Ser & 0.36 & $(1.4)$ & 6.3 & \\
Gly & 0.32 & $(2.1)$ & 4.5 & 0.90 \\
Thr & 0.27 & $(0.7)$ & 3.2 & 0.19 \\
Val & 0.37 & $(2.2)$ & 2.75 & 1.02 \\
Glu & 0.40 & $(2.6)$ & 2.6 & 0.64 \\
Lys & 0.26 & $(1.7)$ & 2.5 & 0.022 \\
& & & & 0.33 \\
Leu & 0.38 & $(2.3)$ & 1.86 & \\
Tyr & 0.33 & $(2.6)$ & 1.83 & 0.48 \\
Try & 0.38 & $(2.5)$ & 1.80 & 0.35 \\
& & & & \\
His & 0.38 & $(1.1)$ & 1.78 & 0.41 \\
Cys & 0.33 & $(0.33)$ & 1.70 & 0.05 \\
Met & 0.37 & $(2.3)$ & 1.65 & 0.23 \\
Arg & 0.38 & $(0.33)$ & 1.63 & 0.79 \\
Phe & 0.34 & $(2.4)$ & 1.51 & 0.47 \\
Ile & 0.38 & $(0.2)$ & 1.42 & 0.05 \\
\hline
\end{tabular}

${ }^{*} \mathrm{~L}=$ d.p.m./ $\mu \mathrm{g}$ of left tectal protein, $\mathrm{R}=\mathrm{d}$.p.m./ $\mu \mathrm{g}$ of right tectal protein. See text for details and discussion.

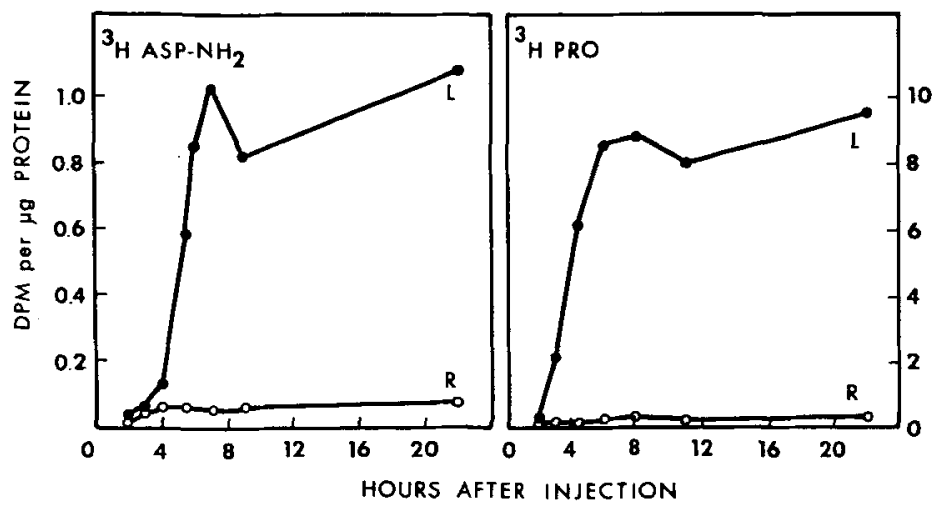

FIG. 3.-Labelling of protein in the left and right optic tecta after the intraocular injection of $\left[{ }^{3} \mathrm{H}\right]$ asparagine $(0.52 \mu \mathrm{Ci}, 0.41 \mathrm{nmol})$ or $\left[{ }^{3} \mathrm{H}\right]$ proline $(2.5 \mu \mathrm{Ci}, 0.31 \mathrm{nmol})$. Groups of four to five tecta were processed together for each point. L, left tectum; $R$, right tectum.

its validity was not established. In contrast to other amino acids, the use of proline resulted in a left-right difference in TCA-soluble radioactivity (Fig. 4). The difference in TCA-soluble radioactivity was much lower and developed slightly later than the difference in protein radioactivity. For the left tectum, unlike the situation with $\left[{ }^{3} \mathrm{H}\right]-$ leucine, TCA-soluble radioactivity reached only about 5 per cent of the plateau level 


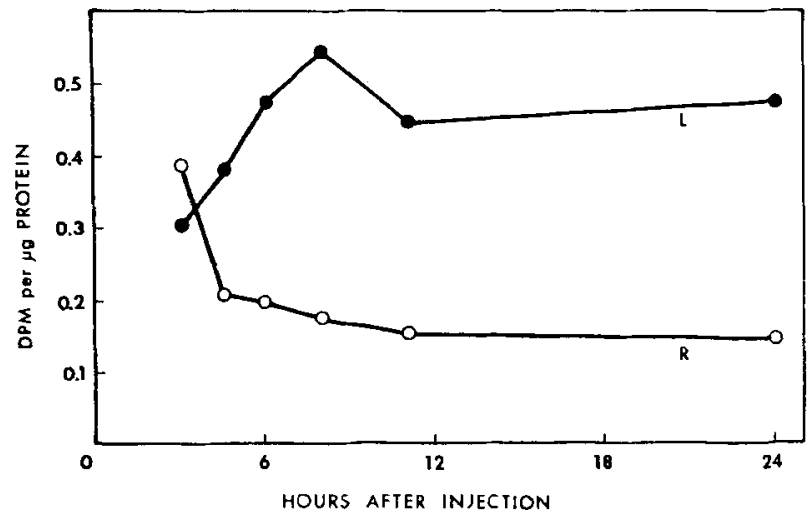

FIG. 4.- Labelling of the TCA-soluble fraction of the left and right optic tecta after the intraocular injection of $\left[{ }^{3} \mathrm{H}\right]$ proline. Results are taken from the experiment illustrated in Fig. 3. Radioactivity is expressed as d.p.m. per $\mu \mathrm{g}$ of homogenate protein.

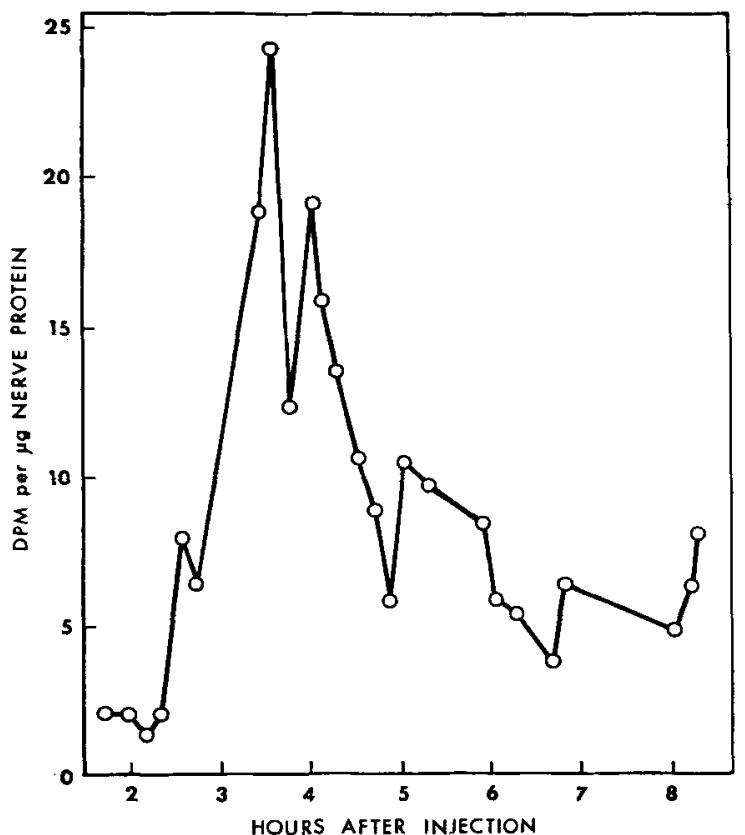

FIG. 5.-Labelling of protein in the right optic nerve at various times after injection of $\left[{ }^{3} \mathrm{H}\right]$ proline $(1.8 \mu \mathrm{Ci}, 0.22 \mathrm{nmol})$ into the right eye. Measurements were made in the portion of the nerve between the base of the eye and the optic chiasm (see Methods for details). 
of protein radioactivity. When the TCA-soluble fraction of the left tectum was extracted with ether, concentrated, and chromatographed on a thin layer plate of silicagel G, 60 per cent of the radioactivity migrated with free proline.

The movement of labelled protein in the optic nerve was also studied. Individual fish were injected in the right eye with $1.8 \mu \mathrm{Ci}$ of $\left[{ }^{3} \mathrm{H}\right]$ proline $(8 \mathrm{Ci} / \mathrm{mmol})$ and the portion of the right optic nerve between the base of the eye and the optic chiasm was removed at various times and the protein analysed for radioactivity (Fig. 5). A peak of radioactive protein passed through the nerve prior to the arrival of radioactivity in the tectum. The radioactive protein apparently did not enter the anterior portion of the nerve until about $2 \mathrm{~h}$ after injection.

Effect of temperature. To examine systematically the effect of temperature on protein labelling and transport, groups of fish were kept at $10^{\circ}, 16^{\circ}$ or $23^{\circ} \mathrm{C}$ for 2 days, then injected with $\left[{ }^{3} \mathrm{H}\right]$ proline. Both the extent of labelling and the time of arrival of transported protein in the tectum were highly dependent on the temperature of the fish (Fig. 6).

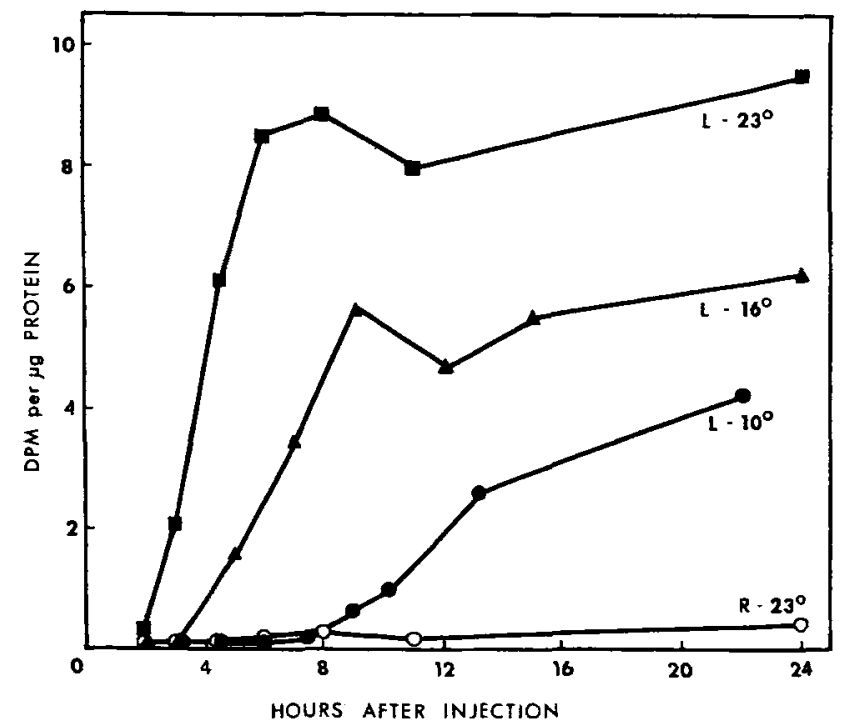

FrG. 6.-Labelling of protein in the optic tectum of fish stored at various temperatures. Fish were stored at the stated temperatures for 2 days prior to ocular injection of $\left[{ }^{3} \mathrm{H}\right]-$ proline $(2.5 \mu \mathrm{Ci}, 0.31 \mathrm{nmol})$. Groups of four fish were pooled for each point. $\mathrm{L}$, left tectum; $R$, right tectum.

Subcellular distribution of rapidly transported protein. Tectal homogenates were subfractionated as described under Methods and fractions were assayed for chemical and enzymic markers (Table 2). The data confirmed the expected composition of the various fractions. The crude nuclear and microsomal fractions were enriched in DNA and RNA respectively. The synaptosomes were rich in acetylcholinesterase and the purified mitochondria had the highest specific activity of succinate-INTreductase. Of the crude mitochondrial subfractions, only the myelin showed detectable amounts of cerebroside. 


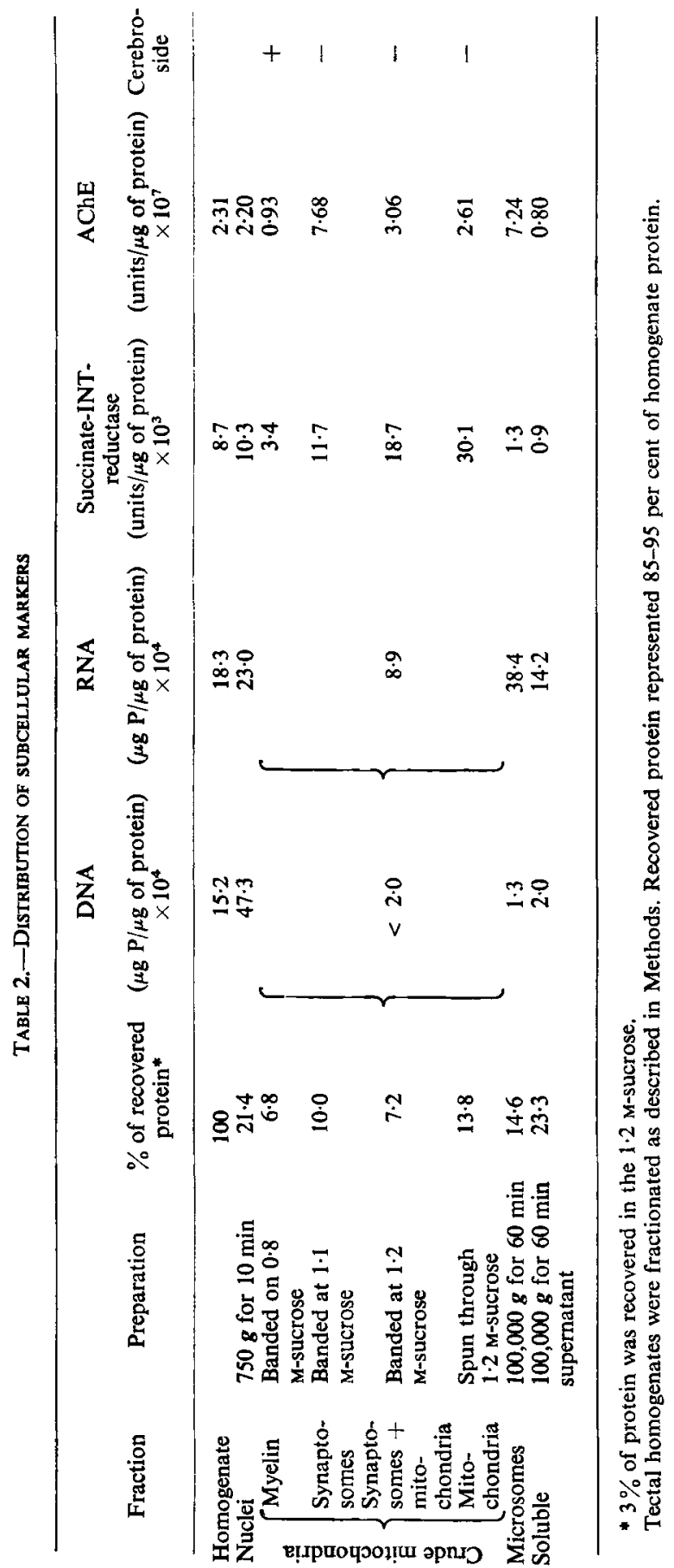


The distribution of radioactive protein in subcellular fractions of $\left[{ }^{3} \mathrm{H}\right]$ prolinelabelled tecta ( $8 \mathrm{~h}$ after injection) is summarized in Fig. 7. Since the results have been plotted as d.p.m. per mg of protein as a function of $\mathrm{mg}$ of protein, the area of each rectangle is proportional to the total radioactivity in that fraction. Right tectal labelling remained relatively minor for all fractions. The rapidly transported protein appeared to be mainly affiliated with particulate material. Nuclei that were further purified by centrifugation through 2 M-sucrose (see Methods) had a specific radioactivity of 1.2 d.p.m. per $\mu \mathrm{g}$, or roughly one-third of that of the crude nuclear fraction.

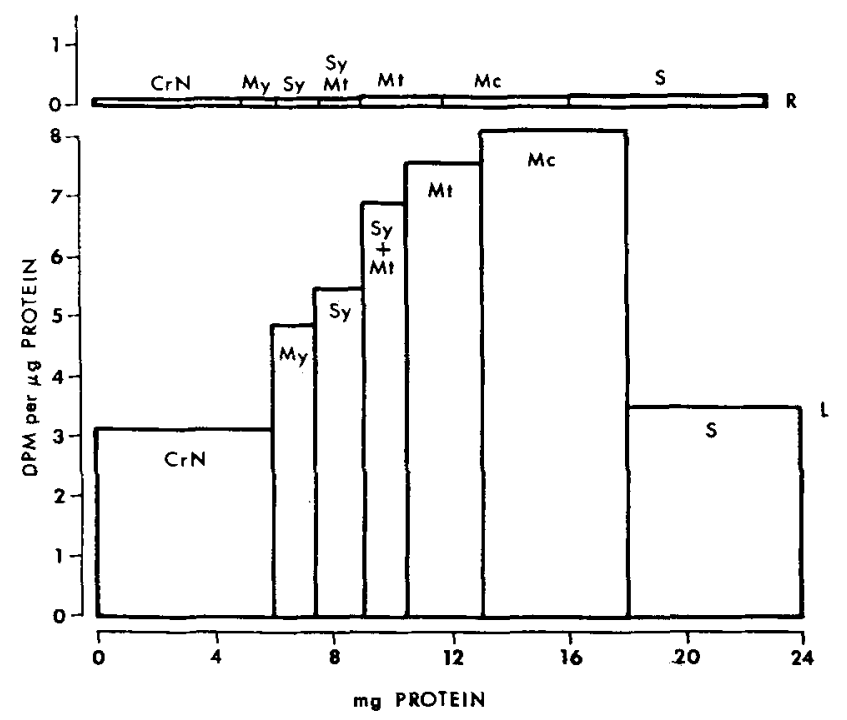

Fig. 7.-Labelling of subcellular fractions of left and right tecta after injection of $\left[{ }^{3} \mathrm{H}\right]-$ proline $(2.5 \mu \mathrm{Ci}, 0.31 \mathrm{nmol})$. Tecta from 40 fish were pooled and fractionated as described in Methods. The area of each rectangle is proportional to the radioactivity in that fraction. L, left tectum; R, right tectum; CrN, crude nuclear; My, myelin; Sy, synaptosomes; Mt, mitochondria; Mc, microsomes; S, soluble. Radioactivity in left tectal fractions (in d.p.m.) was as follows: $\mathrm{CrN}, 18,500 ; \mathrm{My}, 6600 ; \mathrm{Sy}, 7700 ; \mathrm{Sy}+\mathrm{Mt}, 8800$; Mt, 18,$400 ; \mathrm{Mc}, 40,400 ; \mathrm{S}, 20,300$.

The synaptosomal, myelin and mitochondrial subfractions were all extensively labelled. The specific radioactivity of the myelin subfraction was unaltered by washing twice with distilled water and resedimentation on $0.8 \mathrm{M}$-sucrose. To test the possibility that a significant fraction of the transported protein might be proteolipid, the prolinelabelled homogenate was mixed with 19 vol. of chloroform-methanol $(2: 1, \mathrm{v} / \mathrm{v})$ and filtered. Only 3 per cent of the initial radioactivity was recovered in the filtrate containing proteolipid. The purity of the mitochondrial fraction was assessed by recentrifugation (SW-40 rotor, $130,000 \mathrm{~g}$ for $1 \mathrm{~h}$ ) on a $0.8-2 \cdot 0 \mathrm{M}$ linear sucrose gradient. Comigration of succinate-INT-reductase activity, absorbance at $280 \mathrm{~nm}$ and radioactivity as a single band provided further evidence that the mitochondria were labelled.

The microsomal fraction exhibited both the highest specific radioactivity and the 
greatest percentage of the total radioactivity of all the fractions examined. When the microsomal fraction was lysed with deoxycholate and separated into ribosomal and membrane fractions on a $15-40$ per cent $(w / v)$ linear sucrose gradient, essentially all of the radioactivity migrated with the membranes.

Refractionation of labelled subcellular protein. The possibility existed that the radioactivity found in particulate fractions such as myelin, microsomes and mitochondria might be attributable to protein(s) of high specific radioactivity which were normally soluble in vivo, but which were bound to these particles under the conditions of homogenization. To test this possibility, $1.3 \mathrm{mg}$ of labelled, soluble protein were added to $14 \mathrm{mg}$ of unlabelled homogenate and the mixture was refractionated as described in Methods. The radioactivity was distributed as follows: nuclear fraction, 3.3 per cent; crude mitochondrial fraction, 2 per cent; microsomes, $9 \cdot 1$ per cent; supernatant, 85.6 per cent. Alternatively, there might be proteins which were normally particulate, but which underwent extensive exchange with other particles during homogenization. To gain some insight into this question with regard to mitochondria, portions of isolated labelled fractions were each added to $14 \mathrm{mg}$ of unlabelled homogenate and refractionated. Labelled myelin $(0.35 \mathrm{mg})$, synaptosomes $(0.60 \mathrm{mg})$ and microsomes $(0.63 \mathrm{mg})$ contributed respectively $2,2.7$, and 0.7 per cent of their redistributed radioactivity to the mitochondrial fraction.

Localization of radioactivity in labelled protein. Samples of labelled protein isolated from the left tectum were hydrolysed and chromatographed as described under Methods. With $\left[{ }^{3} \mathrm{H}\right]$ asparagine as precursor, 65 per cent of the recovered activity migrated as aspartic acid (derived from aspartic acid and asparagine). With [ $\left.{ }^{3} \mathrm{H}\right]$ proline as the precursor, $>90$ per cent of the recovered radioactivity comigrated with free proline.

\section{DISCUSSION}

The results obtained with injection of $\left[{ }^{3} \mathrm{H}\right]$ leucine (Fig. 1) are similar to those reported by MCEWEN and GRAFSTEIN (1968). Possible decreases in activity at later times, suggested by the data in Fig. 1, were not borne out in other experiments with leucine involving long time intervals, or with the other amino acids shown in Fig. 3. Analysis of the total tectal radioactivity used in these experiments permits study of the rapidly transported protein for several days after injection, after which results are complicated by the arrival of the slowly transported proteins. The similarity in the amounts of left and right-TCA-soluble radioactivities supports the conclusion that transport of protein and not transport of free leucine and its subsequent local incorporation accounts for the higher degree of labelling of the left tectum. The labelling in the right tectum is presumably due to incorporation of $\left[{ }^{3} \mathrm{H}\right]$ leucine brought to the brain via the blood. Such labelling must occur on the left side to an equal extent, so that to measure transported radioactivity we calculated the difference, $L$ (d.p.m. $/ \mu$ g protein) $-\mathrm{R}$ (d.p.m./ $\mu$ g protein). In the experiment shown in Fig. 1, this correction was very large, with roughly 50 per cent of the left tectal radioactivity representing non-transported protein.

Clearly, for purposes of further characterization of the rapidly transported protein it is desirable to decrease such background labelling. One means of accomplishing this is to introduce a physiological 'chase' of unlabelled leucine a short time after the intraocular injection of $\left[{ }^{3} \mathrm{H}\right]$ leucine (Fig. 2). Alternatively, McEWEN and GrafSTEIN (1968) 
were able to achieve a similar augmentation in the left-right difference by an intracranial injection of acetoxycycloheximide, an inhibitor of protein synthesis.

A superior method for specifically labelling the transported protein is the use of different amino acid precursors (Table 1). For most purposes the use of either $\left[{ }^{3} \mathrm{H}\right]$ proline or $\left[{ }^{3} \mathrm{H}\right]$ asparagine (Fig. 3) allows the study of protein transport in the optic tectum with negligible correction for background labelling. Both amino acids are incorporated into transported protein more efficiently than leucine and both enter the right tectal (non-transported) protein less efficiently than leucine (Table 1). $\left[{ }^{3} \mathrm{H}\right.$ ]Proline enters left tectal protein as proline and $\left[{ }^{3} \mathrm{H}\right]$ asparagine enters largely as asparagine and/or aspartic acid. The low efficiency of right tectal incorporation with proline may reflect the fact that only one-fifth as much of the injected radioactive proline enters the TCA-soluble fraction of the right tectum compared with the labelled leucine. This difference might reflect metabolism of proline after it leaves the eye or its dilution with a large systemic pool of proline. In contrast, the fraction of injected radioactivity from asparagine reaching the TCA-soluble fraction of the right tectum is roughly comparable to that seen with labelled leucine, but only one-third as much of this radioactivity derived from asparagine is incorporated into protein.

The left-right differences in TCA-soluble fractions of tectum labelled with $\left[{ }^{3} \mathrm{H}\right]-$ proline are not seen with other amino acids. Since the absolute amounts of radioactivity are very small, and since the difference in TCA-soluble radioactivity develops somewhat later than the appearance of radioactivity in protein in the left tectum, it is unlikely that the TCA-soluble material is precursor to more than a minor fraction of the protein radioactivity of the left tectum. In the proline experiments, most of the TCA-soluble radioactivity of the left tectum was free proline. It may arise from breakdown of some of the newly arrived protein or perhaps reflect transport of small amounts of free proline. The possibility of breakdown is intriguing in view of the frequently observed dip in specific radioactivity of left tectal protein about the time the left tectal acid-soluble radioactivity from proline is increasing.

In kinetic studies with proline, asparagine, and leucine (Figs. 1-3), the rapidly transported protein accumulated in the tectum over a shorter and more discrete time interval than that indicated in the study by MCEwEN and GRAFSTEIN (1968). This difference may reflect the use of additional early time-points in the present study, a procedure which revealed the presence of a $3-4 \mathrm{~h}$ delay in the arrival of any of the transported protein. This delay indicates that proteins are moving at similar rates with no significant subpopulation of very rapid transport. Since it takes $3-4 \mathrm{~h}$ for protein to traverse the $6 \mathrm{~mm}$ of optic nerve in our goldfish, the apparent rate of transport is 40-50 mm per day. However, since the experiment shown in Fig. 5 indicates that 1-2 h is required for the transported protein to enter the anterior half of the nerve, the rate of transport within the nerve per se may be closer to $70-100 \mathrm{~mm}$ per day. These estimates of transport rates are for fish stored at $18-20^{\circ} \mathrm{C}$. At lower temperatures the arrival of protein in the tectum is greatly delayed (Fig. 6). Apparently acclimated fish do not restore the higher rates of transport, since fish that were kept at $10^{\circ} \mathrm{C}$ for 15 days showed the same delay in transport as that seen after 2 days at $10^{\circ} \mathrm{C}$. If the rate of transport at $10^{\circ} \mathrm{C}$ is one-third to one-half of the rate at $23^{\circ} \mathrm{C}$, the corresponding rate at $37^{\circ} \mathrm{C}$ would in theory approach the rate of several hundred $\mathrm{mm}$ per day that has been observed in mammalian nerve (LASEK, 1968; OCHS, SABRI and JOHNSON, 1969; SJöSTRAND, 1969; LIVETT et al., 1968). In the fish, absolute levels of isotope incorporation 
are also temperature-dependent (Fig. 6). Thus one way to increase the amount of radioactivity available for analysis from a given injected dose is to use fish stored at relatively high temperatures.

Several studies on axonal transport have led to the conclusion that rapidlytransported protein is very likely highly particulate (SJöSTRAND and KARLSSON, 1969; MCEWEN and GRAFSTEIN, 1968; OCHS et al., 1969). Radioautographic evidence (GRAFSTEIN, 1967) indicates that only the optic (presynaptic) nerve ending layers of the tectum are labelled with rapidly transported protein. Any homogenate or subcellular fraction of whole tectum will therefore be derived from a mixing of labelled and unlabelled tectal areas. The distribution of total radioactivity in various fractions must reflect the distribution of transported protein, but the specific radioactivity of a given fraction is in addition influenced by the composition of the entire tectum. Synaptosomal contents are likely to be released during homogenization either by rupture or by leakage during their formation. As a consequence, labelled synaptosome-derived material might be found in other fractions.

In the present study, only about 20 per cent of the radioactivity found in tectal protein was soluble (Fig. 7). The rest was widely distributed among the particulate subcellular fractions including, as expected, synaptosomes. Although both the crude nuclear and the crude microsomal fractions were extensively labelled, purified nuclei and ribosomes showed only low levels of radioactivity. Since these structures are absent presynaptically, these findings support the radioautographic evidence that there is little or no trans-synaptic migration of rapidly transported protein.

Since the labelling of the free mitochondrial fraction (Fig. 7) does not appear to represent non-specific binding of proteins from other fractions, as indicated by experiments in which labelled fractions were added back to unlabelled homogenates, and since postsynaptic mitochondria are not likely to be labelled, we presume that this radioactivity is in mitochondria released from nerve endings damaged during bomogenization. This suggests that there is rapid transport of mitochondria or of proteins which are selectively associated with mitochondria in nerve terminals. BARONDEs (1966) observed both slow and rapid labelling of synaptosomal mitochondria from mouse brain but attributed the substantial degree of rapid labelling to contamination and/or the incorporation of precursor $\left(\left[{ }^{3} \mathrm{H}\right]\right.$ leucine $)$ in the nerve endings. In our studies with $\left[{ }^{3} \mathrm{H}\right]$ proline in fish, neither of these factors appears to account for the rapid labelling. It remains possible that some additional mitochondria migrate slowly (Weiss and PILLAI, 1965; BARONDES, 1966).

The finding that labelling of the myelin fraction is not diminished by hypotonic washes raises the question of whether some myelin protein might be of neural origin. The observation of large amounts of radioactivity in the microsomal fraction is consistent with results of studies on rapid axonal transport in other animals (OCHS et al., 1969; SJÖSTRAND and KARLSSON, 1969 ; SJöSTRAND, 1970). After recentrifugation on a continuous sucrose gradient, much of the radioactivity is localized in the region of 0.8 $1.0 \mathrm{M}$-sucrose, a behaviour suggestive of the presence of small synaptosomes, synaptosomal ghosts or damaged synaptosomes (WHITTAKER, MICHAELSON and KIRKLAND, 1964).

Much remains to be learned about the metabolism of rapidly transported protein. The fact that its life-time in the tectum can be measured in weeks or perhaps even months (GrafsTEIN and MCEWEN, 1968) indicates that the amount of protein trans- 
ported per day at the rapid rate must be small. Estimates based on the proline incorporation data (Fig. 3) appear to confirm this. If the concentration of free proline in the eye is similar to that of the brain $(0.25 \mu \mathrm{mol} / \mathrm{g}$; LIM and AGRANOFF, 1969), and if the volume of the eye is about $30 \mu \mathrm{l}$, then the injected amount of proline would be diluted 25 -fold by the endogenous pool in the eye. If one accepts this assumption and that proline residues represent about 5 per cent of the total amino acids in transported protein, and that labeling in the eye is complete within $1 \mathrm{~h}$, then the 0.12 per cent of the injected isotope which enters rapidly transported protein will represent the transport of $9.0 \mathrm{pmol}$ of proline, or $180 \mathrm{pmol}$ of amino acids per hour. This corresponds to the addition of less than $0.5 \mu \mathrm{g}$ of protein per day to a tectum containing $50-100 \mu \mathrm{g}$ of protein in the nerve ending layer for the optic nerve (if the percentage of tectal protein is roughly proportional to the percentage of the tectal cross-sectional area represented by the nerve ending layer.)

The rapid transport of proteins of slow turn-over may in large part represent the systematic replacement of metabolites, macromolecules and organelles which are slowly degraded during the normal functioning of the synapse. The fact that they are rapidly transported may reflect a cellular economy that minimizes the time between synthesis in the perikaryon and utilization at the nerve ending. In addition to such a maintenance role, there is the real possibility that certain of the rapidly moving proteins are involved in metabolic response to physiological or environmental events.

Acknowledgements-The authors are indebted to Mrs. Marianne ANDrews, Mrs. EnCY Tadayyon and Mr. W. ARMSTRONG for valuable technical assistance.

\section{REFERENCES}

BARONDES S. (1966) J. Neurochem. 13, 721.

BLIGH E. G. and Dyer W. J. (1959) Can. J. Biochem. 37, 911.

Brenner M., Niederwieser A, and Pataki G. (1969) In Thin-Layer Chromatography (Edited by Stahl E.) p. 730. Springer-Verlag, New York.

Casola L. and Agranoff B. W. (1968) Biochem. biophys. Res. Commun. 30, 262.

Casola L., Lim R., Davis R. and Agranoff B. W. (1968) Proc. natn. Acad. Sci. U.S.A. 60, 1389.

DAvIS G. A. (1968) The Behavior of Multiple Molecular Forms of Cholinesterase Ph.D. Thesis, Univ. of Michigan, Ann Arbor

Ellman G. L., Courtney D., Andres V. and Featherstone R. M. (1961) Biochem. Pharmac. 7, 88.

GrAFstein B. (1967) Science 157, 196.

KarLsSON J. and Suöstrand J. (1968) Brain Res. 11, 431.

LASEK R. (1968) Brain Res. 7, 360.

LIM R, and Agranoff B. W. (1969) J. Neurochem. 16, 431

LivetT B. G., GefFen L. B. and AUStin L. (1968) J. Neurochem. 15, 931.

Lowry O. H., Rosebrough N. J., FarR A. L. and Randall R. J. (1951) J. biol. Chem. 193, 265.

LuBINSKa L. (1964) In Mechanisms of Neural Regeneration. Progress in Brain Research Vol. 13

(Edited by Singer M. and Schadé J. P.), p. 1. Elsevier, Amsterdam.

MANS R. J. and Novelui G. D. (1961) Arch. Biochem. 94, 48.

MCEwen B. S. and Grafstern B. (1968) J. Cell Biol. 38, 494.

OCHS S. and JoHNSON J. (1969) J. Neurochem. 16, 845.

OCHS S, SABRI M. I. and Johnson J. (1969) Science 163, 686.

SANTEN R. J. and AGRanofr B. W. (1963) Biochim. biophys. Acta (Amst.) 72, 251.

Sellinger O. Z. and HiATt R. A. (1968) Brain Res, 7, 191.

SJöstrand J. (1969) Exp. Brain Res. 8, 105.

Suöstrand J. (1970) Brain Res. 18, 461.

Sü̈STRAND J. and KarLsSON J. O. (1969) J. Neurochem. 16, 833.

Von Hungen K. Mahler H. R. and MOORE W. J. (1968) J. biol. Chem. 243, 1415

Wagner H. L., Hörhammer U. and WolfF P. (1961) Biochem. Z. 334, 175.

Werss, P. (1967) Neurosciences Res. Prog. Bull. 5, 371.

Weiss P. and Pillai A. L. (1965) Proc. natn. Acad. Sci. U.S.A. 54, 48.

WhitT Aker V. P., Michaelson I. A. and KirkLAND R. J. A. (1964) Biochem. J. 90, 293. 